\title{
Zinc oxide enriched peat influence Escherichia coli infection related diarrhea, growth rates, serum and tissue zinc levels in Norwegian piglets around weaning: five case herd trials
}

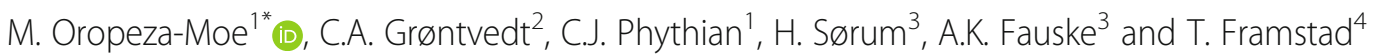

\begin{abstract}
Background: Zinc oxide (ZnO), commonly used to control post-weaning diarrhea in piglets, has been highlighted as of potential concern from an environmental perspective. The aim of this field trial was to examine effects of different sources and levels of $\mathrm{ZnO}$ added to peat on average daily weight gain (ADG), fecal score in pens and serum and tissue zinc (Zn) levels around time of weaning in order to reduce the environmental impact without loss of the beneficial effect of $\mathrm{ZnO}$ on intestinal health and growth. Five case herds with enterotoxic colibacillosis challenges were included. The piglets entered the study aged three or five weeks. All piglets received a commercial diet containing $<150 \mathrm{mg} \mathrm{Zn/per} \mathrm{kg}$ of complete feed. Four treatment groups received commercial peat added A: uncoated ZnO, B: lipid microencapsulated ZnO, C: solely commercial peat or D: no peat (Farms 2 and 3).

Results: At Farms 1, 2 and 3, a significant effect of treatment was identified for fecal score $(P<0.05)$. Treatment A led to lower fecal scores compared to treatments $C(P<0.05)$ and $D(P<0.01)$. At Farms 2 and 3, there was a significant difference in individual average daily weight gain (iADG) between treatment $A$ and $D(P<0.05)$. The iADG of piglets receiving treatment $B$ did not differ significantly from treatment $A$.

Conclusions: In 2016, The European Medicines Agency's Committee on Veterinary Medicinal Products concluded that the benefits of $\mathrm{ZnO}$ for the prevention of diarrhea in pigs do not outweigh the risks to the environment. Effective alternative measures to reduce the accumulation of $\mathrm{Zn}$ in the environment have not been identified. Our results imply that peat added low concentration of both coated and uncoated $\mathrm{ZnO}$ influences the gut health of weaned piglets reflected by enhanced weight gain and reduced occurrence of diarrhea. This preventive approach certainly represents a favourable alternative in the "One Health" perspective. It will also contribute to reduced antibiotic use in pig farming while diminishing the environmental consequences caused by $\mathrm{ZnO}$.
\end{abstract}

Keywords: Piglet, ZnO enriched peat, Coated ZnO, Diarrhea, Growth rates, Serum ZnO, One Health

\footnotetext{
* Correspondence: marianne.oropeza-moe@nmbu.no

'Department of Production Animal Clinical Sciences, Norwegian University of

Life Sciences (NMBU) Faculty of Veterinary Medicine, Campus Sandnes,

Sandnes, Norway

Full list of author information is available at the end of the article
} 


\section{Background}

Piglets are vulnerable to Escherichia coli (E. coli) infections around weaning since circulating plasma antibodies are low and passive intestinal immunity provided by antibodies in the sow's milk (IgA) is lost when the sow and piglets are separated $[1,2]$. The separation from the sow, a different environment, commingling with unfamiliar piglets, hierarchy establishment through fighting and abrupt change in nutrition, are major changes that show a negative influence on immune functions and may result in $E$. coli associated post-weaning diarrhea (PWD) or edema disease (ED) [3-7].

E. coli causing PWD or ED enter the organism by ingestion and colonize the small intestine after attaching to porcine receptors on the enterocytes with fimbrial adhesins. The degree of colonization determines whether clinical manifestations occur or not. Fimbriae-designated E. coli $\mathrm{F} 8^{+}$and $\mathrm{F}^{+}$are typical pathogens involed in ED and PWD, E. coli $\mathrm{F}^{+}, \mathrm{F}^{+}$and $\mathrm{F}_{4} 1^{+}$can occur in suckling pigs $[8,9]$. Enterotoxigenic E. coli (ETEC) strains cause watery diarrhea and systemic disease in piglets due to their ability to colonize the intestine through expression of adhesins and the ability to produce the toxins heat labile (LT) or heat stable (ST) enterotoxins as well as Shigatoxin 2e (STx2e) [10-12]. The ED causing hemolytic E. coli F18ab ${ }^{+}$produce Stx2e [13].

Since 2006, the use of antibiotic growth promoters in piglets has been banned in Europe [14]. As a consequence, there has been an increase in some uses of 'therapeutic' antibiotics and possibly switches to different and more modern antibiotics [15]. Therefore, AR development in production animals remain a serious problem in consumer health protection. Various natural materials such e.g. organic acids or zinc ( $\mathrm{Zn}$ ) have been tested as alternatives to antibiotics.

Zinc oxide $(\mathrm{ZnO})$ at therapeutic concentrations (2000 ppm or more) has been widely used to prevent porcine colibacillosis, improve suboptimal weight gain and feed efficiency. The small-intestinal mucosa is altered by feeding of $3000 \mathrm{ppm} \mathrm{Zn}$ for 14 days [16], thus potentially increasing the absorptive capacity of the small intestine and consequently improving growth. Dietary treatment with $\mathrm{ZnO}$ has been associated with significant differences in the transcript abundance of several genes. Dietary $\mathrm{ZnO}$ supplementation influence metallothionein mRNA expression in the intestine and liver, enhances expression of the tight junction genes occludin and ZO-1 both at mRNA and protein levels and further enhances small intestinal IGF-I and IGF-I receptor gene expression, which can explain improved intestinal health [16-18]. An influence on the gastrointestinal microbiota in weaned piglets has been described [19-21]. Reduced fermentation of digestible nutrients in the proximal part of the gastrointestinal tract may render more available energy for the host and contribute to the growth-promoting effect of high dietary $\mathrm{ZnO}$ doses [20].

$\mathrm{ZnO}$ tend to dissociate after uptake in the low $\mathrm{pH}$ environment of the anterior gastrointestinal tract, allowing interaction with other nutrient and ingredient potentially leading to impaired absorption, and thus decreased bioavailability [22]. Long term use of pharmacological $\mathrm{ZnO}$ concentrations (2000 to $4000 \mathrm{mg} \mathrm{Zn/} \mathrm{kg)} \mathrm{to}$ pigs feed, increases the concentration of $\mathrm{Zn}$ in the pig manure and results in $\mathrm{Zn}$ accumulation of arable land $[23,24]$. Accumulation of $\mathrm{Zn}$ in soils may impose a toxicity risk on plants and micro-organisms [25]. Therefore, European feed legislation limits total dietary $\mathrm{Zn}$ in complete feed to $150 \mathrm{ppm}$ [26]. Recent studies also support the assertion that $\mathrm{Zn}$ in feed may favour or select for AR [27-32].

Microencapsulated $\mathrm{ZnO}$ products are available on today's market. According to the manufacturers, lipid microencapsulation avoids ionization of the active component in the animal stomach. Therefore biological properties are preserved and the biological effects are excerted in the animals' small intestine [33, 34]. Studies have stated that coated $\mathrm{ZnO}$ at inclusion levels between 100 and 200 ppm in basal diets show similar effects as uncoated $\mathrm{ZnO}$ on growth promotion, reduced incidence of diarrhea and microbiota composition regulation [33-36].

A different approach to prevent intestinal disease in weaned piglets is peat supplementation, which has been associated with beneficial effects on health status, growth and mortality rates [37-39]. Peat contain humic substances including humic acids showing detoxifying properties because of chelate formation with potentially toxic substances such as heavy metals [40, 41], stimulation of digestion [42] and anti-inflammatory and antiviral effects $[43,44]$. Due to its low $\mathrm{pH}$ (3.0 to 5.5) peat causes a reduction of the $\mathrm{pH}$ of the intestinal contents with subsequent reduced growth of Enterobacteriaceae [38]. Humic and fulvic acids have shown to improve nutrient uptake in suckling piglets [45]. Limited literature is available regarding the optimal dosage of peat preparations to piglets. An inclusion level of 0,5\% humic substances to dietary treatments may improve ADG in weaned piglets [46]. Independent studies have stated that the effects of batches containing dietary humic substances are variable, warranting further investigation $[39,46]$. An important prerequisite when applying peat supplementation to animals, is the monitoring of potentially pathogenic mycobacteria sometimes present in batches of peat preparations [47, 48]. These case herd trials aimed to explore the effects of different $\mathrm{ZnO}$ sources and $\mathrm{ZnO}$ levels in peat preparations on pre- and postweaning fecal consistency and weight gain. Additionally, initial and final Zn-serum concentrations, liver and kidney $\mathrm{Zn}$ levels were examined at two of the farms. 
A feed additive consisting of peat and uncoated or coated $\mathrm{ZnO}$ was produced. We anticipated that this preparation would show both peat and $\mathrm{ZnO}$ derived beneficial effects and therefore low $\mathrm{ZnO}$ levels added to peat should show the same effects as pharmacological $\mathrm{ZnO}$ levels added to feed. We hypothesized that low level $\mathrm{ZnO}$ enriched peat would improve piglet average daily weight gain (ADG) and reduce fecal score.

\section{Methods}

Preparation and quality control of $\mathrm{Zn}$ oxide enriched peat Commercial peat (Pluss Avvenningstorv, Felleskjøpet, Norway) was used as the peat substrate in treatments A, B and C. It contained $31.1 \%$ dry matter and $<5 \mathrm{mg} \mathrm{Zn/} \mathrm{kg} \mathrm{at}$ a pH of 5.3. The contents of molds and yeasts were below $100 \mathrm{CFU} / \mathrm{g}$, no Salmonella spp. were detected and bacterial colony counts $\left(30^{\circ} \mathrm{C}\right)$ were $9000 \mathrm{CFU} / \mathrm{g}$. The commercial peat was analyzed by Alcontrol Laboratories (Stjørdal, Norway) by employing standard methods (Dir152/2009/ EU [49], ISO 6869 [50], NMKL 98 [51], NordVal no: 014 [52], Tecra [53], NS-EN ISO 10523:2012 [54]).

$\mathrm{Zn}$ sources used to prepare the peat supplements included uncoated Normin Sink ${ }^{\oplus}$ ( $8 \%$ Zn, Normin, Hønefoss, Norway) and lipid microencapsulated Zincoret ${ }^{\circ}$ S (0.3\% Zn, Vetagro S.p.A, Reggio Emilia, Italy). ZnO enriched peat was prepared by Fossli AS (Frosta, Norway). Peat A was commercial peat added $2819 \mathrm{mg} / \mathrm{L}$ uncoated $\mathrm{ZnO}(2255 \mathrm{mg} \mathrm{Zn/L})$. Peat B was commercial peat added $321 \mathrm{mg} / \mathrm{L}$ coated $\mathrm{ZnO}(257 \mathrm{mg} \mathrm{Zn} / \mathrm{L})$. Peat $\mathrm{C}$ was commercial peat without $\mathrm{ZnO}$-additives. Uncoated or coated $\mathrm{ZnO}$ was added to a batch of peat and transported in sacks of $80 \mathrm{~L}$. The farmers and veterinarians (authors) were double-blinded to the composition of the treatment groups. The $\mathrm{Zn}$ content in peat preparations was analyzed prior to the start of the trial by standard methods at an accredited laboratory (Labnett Laboratories, Stjørdal, Norway) [55]. Peat was analyzed at the Norwegian Veterinary Institute in Oslo by a polymerase chain reaction to identify strains of Mycobacterium avium with specific primers (IS901-IS902) [56, 57]. No pathogenic Mycobacteria avium were detected by applying IS901IS902 specific primers on samples isolated from the peat preparation.

\section{Case herds}

Five Norwegian commercial pig herds with a documented history of clinical disease associated with $E$. coli infections were recruited (Table 1). Fecal samples from the case herds were submitted to serological testing (agglutination in microtiterplates with boiled antigen and single $\mathrm{O}$-antisera) or $\mathrm{PCR}$ analyses conducted at the Norwegian Veterinary Institute or at the Norwegian School of Veterinary Science, respectively. At Farm 1, diarrhea occurred repeatedly around 3 weeks of age. At
Table 1 Documented virotypes and serotypes of E. coli causing ETEC and STEC at the case herds 1 to 5 prior to performing trials

\begin{tabular}{lllll}
\hline Farm & Piglet genotype & Pathotype & Virotype & O serogroups \\
\hline 1 & LYLL & ETEC & F4 & \\
2 & LYHH & ETEC & & 0149 \\
3 & LYLL & ETEC & & 0138 \\
4 & LYLD & ETEC & LT:STb & \\
5 & LYHH & STEC & Stx2e:F18 & O139 \\
\hline
\end{tabular}

The pathotypes, virotypes and $O$ serogroups verified at the case herds 1 to 5 prior to recruitment for the trials are listed. Strains of E.coli isolated from fecal samples of piglets after post mortem examination were either forwarded by the veterinarian in charge to the Norwegian Veterinary Institute for serotype determination (agglutination in microtiterplates with boiled antigen and single O-antisera) or to the Norwegian School of Veterinary Science in Oslo for virulence pattern determination (PCR analysis). The pathotype Enterotoxigenic E. coli (ETEC) was found at Farms 1 to 4 while Shiga-toxigenic E. coli (STEC) was found at Farm 5. Virotypes at Farms 1, 4 and 5 were F4, LT:STb and Stx2e:F18, respectively. The $O$ serogroups 0149,0138 and 0139 were identified at Farms 2, 3 and 5, respectively. Genetic combinations of piglets included Landrace $x$ Yorkshire (LY) $x$ Landrace $x$ Landrace (LL) (LYLL) at Farm 1. At Farm 2, LY $x$ Hampshire/Hampshire (HH) (LYHH) were used. At Farm 3, LYLL piglets were utilized. LY $x$ Landrace/Duroc (LYLD) and LYHH were used at Farms 4 to 5 , respectively

Farms 2-4, PWD was observed regularly. At Farm 5, ED had caused significant losses across multiple batches.

All dams were vaccinated against $E$. coli (recombinant adhesin F4 (F4ab, F4 ac, F4ad), recombinant adhesin F5, field strain adhesins F6 and F41) for passive transfer of lactogenic immunity in the suckling piglets.

\section{Animal management and measurements}

The trials began with piglets aged two weeks on Farm 1 whilst on Farms 2-5, piglets close to five weeks (the average weaning age in Norway) of age were enrolled in the trials. Across all farms, piglets (females and castrated males) were weaned at 32 to 33 days of age $(10.16 \pm 1.80 \mathrm{~kg}$ of bodyweight $(\mathrm{BW}))$. Digital thermometers were used to monitor the room temperatures at Farms 1 to 3 . At Farm 1, room temperature was $18^{\circ}$ $\mathrm{C} \pm 2{ }^{\circ} \mathrm{C}$ and the temperature on the piglet creep floor, measured with a handheld laser device, was $24-25{ }^{\circ} \mathrm{C}$. At Farms 2 and 3, room temperature showed fluctuations (day and night) between 23 and $21{ }^{\circ} \mathrm{C}$ at initiation of the trials. The room temperature was gradually reduced $\left(0.5^{\circ}\right.$ $\mathrm{C}$ per day) and set to $18{ }^{\circ} \mathrm{C}$. At Farms 4 and 5 , the temperature was set to $22^{\circ} \mathrm{C}$ at initiation of the trials and reduced gradually to $18{ }^{\circ} \mathrm{C}$. The light (L): dark (D) periods were $16 \mathrm{~L}: 8 \mathrm{D}$. At Farm 1, the piglets were fed their basic feed on the floor. Restrictive feeding was conducted at Farms 2 and 3 while Farms 4 and 5 practiced ad libitum feeding. The pigs had free access to drinking water. Natural wood shawings were used as bedding material at all farms.

Concentrate feed used at all five trial farms was a standard starter feed (Table 2). Pens of 10 to 12 piglets were allocated to one of three treatments (A to D). A 
Table 2 Composition of basal feed at trial farms

\begin{tabular}{llllll}
\hline Farm: & Farm 1 & Farm 2 & Farm 3 & Farm 4 & Farm 5 \\
Production stage: & PrW $^{\mathrm{a}}$ & PoW $^{\mathrm{b}}$ & PoW & PoW & PoW \\
\hline \multicolumn{5}{l}{ Feed composition } \\
Crude protein (\%) & 16.00 & 19.60 & 18.30 & 18.00 & 18.10 \\
Dry matter (\%) & 88.00 & 88.20 & 86.90 & 87.40 & 88.00 \\
Lysine (\%) & 1.23 & 1.39 & 1.20 & 1.20 & 1.28 \\
Crude fat (\%) & 3.00 & 6.00 & 5.10 & 5.30 & 4.90 \\
Crude ash (\%) & 5.00 & 4.70 & 5.00 & 4.50 & 5.20 \\
Vit. A (IU) & 10,000 & 8000 & 10,000 & 8000 & 10,000 \\
Vit. D (IU) & 1500 & 1300 & 1000 & 1500 & 1500 \\
Vit. E (mg) & 200 & 180 & 150 & 150 & 200 \\
Copper sulphate (mg/kg) & 15 & 26 & 15 & 32 & 15 \\
Sodium selenite (mg/kg) & 0.20 & 0.10 & 0.30 & 0.40 & 0.20 \\
6-phytase (FYT/kg) & 500 & 500 & 1500 & 703 & 500 \\
Zn (mg/kg) & 120 & 141 & 120 & 141 & 120 \\
\hline Compsin & &
\end{tabular}

Composition of basal feed fed at the five trial farms. The levels of crude protein varied between $16 \%$ (Farm 1, preweaning phase) and 19.6\% (Farm 2, postweaning phase). Vitamin levels were comparable. Sodium selenite levels varied between 0.1 and $0.4 \mathrm{mg} / \mathrm{kg}$

aprW: Pre-weaning

${ }^{\mathrm{b}}$ PoW: Post-weaning

farmers consent to include a control group (treatment D) was attained at Farms 2 and 3.

The treatment duration at each case farm was decided based on known challenges with $E$. coli infections and the expected duration of clinical cases based on the farmers previous experiences. E. coli associated diarrhea in suckling piglets from 2 to 4 weeks of age was a documented herd health problem at Farm 1. Therefore, treatments $\mathrm{A}$ to $\mathrm{C}$ were provided from 2 weeks of age until weaning. One liter of peat $\mathrm{A}, \mathrm{B}$ or $\mathrm{C}$ was provided to each pen twice a day. At Farms 2, 3 and 4, experiencing repeated cases of $E$. coli associated PWD, treatments with $1 \mathrm{~L}$ peat/ pen twice a day were initiated at weaning (day 0) and continued for 14 to 17 days.

Farm 5 struggled with repeated cases of E. coli associated ED. Due to the known presence of a highly 'aggressive' E. coli strain, animals received $2 \mathrm{~L}$ daily of treatments $\mathrm{A}, \mathrm{B}$ or $\mathrm{C}$ starting one week before weaning (day -7). The next 2 weeks, the animals received twice the amount of peat compared to Farms 1, 2 and 3; $4 \mathrm{~L}$ daily of treatments A, B or C (day 0-14). The last week, these animals again received $2 \mathrm{~L}$ daily of treatments $\mathrm{A}, \mathrm{B}$ or $C$ (day 15 to 21 after weaning) as the abrupt withdrawal of $\mathrm{ZnO}$ supplementation may favour the growth of Shiga-toxigenic E. coli (STEC).

BW was registered and blood samples were collected from randomly selected and ear tagged piglets at Farms 2 $(n=12)$ and $3(n=6)$ via the external jugular vein prior to study entry at weaning (day 0 ). The same piglets were bled and weighed individually at termination of the trials.
On Farm 1, all piglets in one farrowing unit were ear tagged and the body weight was registered on study entry, at two weeks of age (- day 21, three weeks before weaning) and day 0 (weaning day). On Farms 2 to 5, group weights of pigs within the same pens were recorded on day 0 and on the last day of the trial (day 14-21). Each trial pen was evaluated for clinical signs of disease (depression, signs of dehydration and perineal staining) and fecal consistency scores by the same veterinarian at each farm. Clinical signs of disease were not scored. A standardized four-point categorical fecal scoring system was used (score 1: firm, 2: pasty, 3: loose and 4: liquid feces). Observation of a pen with liquid feces (category 4) was scored as diarrhea, irrespective of the number of piglets affected. Rectal swabs on charcoal transport medium were taken from all piglets with fecal score 4 for bacteriological culture. No antibiotic treatment was applied at the case farms during the trials.

On Farm 2, three animals $(n=3)$ from each group A, $\mathrm{B}, \mathrm{C}$ and $\mathrm{D}$ were euthanized by captive bolt gun and exsanguination on days 7 and 15 of the trial for collection of totally 24 fresh liver and 24 kidney samples.

\section{Serum and tissue $\mathrm{Zn}$ analysis}

Blood samples were collected in $9 \mathrm{ml}$ serum collection tubes coated with clot activator (Vacuette ${ }^{\bullet}$, Med-Kjemi AS, Norway). All samples were directly transported to the laboratory within a maximum of $120 \mathrm{~min}$ following sample collection without any prior chilling. Samples were analysed to determine the following parameters: iron (Fe), inorganic phosphate $(\mathrm{P})$, copper $(\mathrm{Cu})$, zinc $(\mathrm{Zn})$, calcium $(\mathrm{Ca})$, magnesium $(\mathrm{Mg})$ and ceruloplasmin $(\mathrm{Cp})$ levels. Levels of Fe and $\mathrm{P}$ were assessed by a colorimetric method (ABX Pentra 400 Analyzer, Horiba). Cu, Zn, Ca, Mg and $\mathrm{Cp}$ were determined by Atomic absorption spectrometry (AAnalyst 300 Perkin Elmer). Due to limited financial resources, blood sampling was restricted to Farms 2 and 3.

Tissue samples were stored at $-20{ }^{\circ} \mathrm{C}$ until analysis. Inductively coupled plasma mass spectrometry (ICP-MS) was performed by SYNLAB.vet GmbH (Berlin, Germany) to determine $\mathrm{Zn}$ concentrations in liver and kidney samples.

\section{RNA extraction and reverse transcription}

A multiplex PCR analysis was conducted on E. coli isolates from affected piglets at the five farms included in this study. Total RNA from bacterial pellets was extracted using the RNAeasy Mini Kit (Qiagen, Hilden, Germany) according to the manufacturer's instructions (Protocol 4 and 7) including an on-column DNA wipeout treatment (Appendix B1-4). The RNA was eluted in $30 \mu \mathrm{LEPC}$ treated water (Invitrogen) and stored at $-70{ }^{\circ} \mathrm{C}$ until reverse transcription (RT). Gel electrophoresis with $1 \%$ agarose gel was used to confirm that isolated RNA was intact while the concentration and purity of the RNA 
extracts were analyzed by measuring the absorbances at 260 (A260) and $280 \mathrm{~nm}$ (A280) using a NanoDrop ${ }^{\mathrm{TM}}$ ND1000 spectrophotometer (Thermo Scientific, Waltham, MA, USA). Only total RNA samples of high quality with A260/A280 ratios between 1.9 and 2.2 and with tight bands of $18 \mathrm{~S} / 28 \mathrm{~S}$ ribosomal RNA (rRNA) were used for RT.

Reverse transcription was conducted with QuantiTect ${ }^{\oplus}$ RT kit (Qiagen) according to manufacturer's instructions for the synthesis of complementary DNA (cDNA) and included a DNase wipeout treatment. Amounts of $1 \mu \mathrm{g}$ of RNA were used in each $\mathrm{RT}$ reaction conducted in a BioRad T100 (Bio-Rad, Hercules, CA, USA). In addition, to confirm the absence of any contamination with genomic DNA (gDNA) contamination, one RNA sample per round of extraction was randomly chosen and not treated with reverse transcriptase. The cDNA samples were diluted in $180 \mu \mathrm{l}$ of DEPC-treated water and stored at $-70{ }^{\circ} \mathrm{C}$ until.

\section{Multiplex polymerase chain reaction (PCR) analysis}

The E. coli strains isolated at the five case farms were characterized by applying primer sequences obtained from previous publications, targeting for the following genes/ virulence factors: (a) estB/ STb [58], (b) estA/ STa [59], (c) eltB/ LT [60], Stx2e (A subunit) [61], faeG/ F4 [62], fanA/ F5 [63], fasA/ F6 [64], fedA/ F18 [65] and fedA subunit/ F41 [66].

\section{Statistical analyses}

Data maintained on individual animal and pen-level measurements were managed in Excel (Microsoft, Windows). Data analyses were performed in STATA version 13.1 (StataCorp LP, College Station, TX) and JMP ${ }^{\ominus}$ Pro version 12.1.0 (Cary, NC, USA). Descriptive statistics and graphical plots were used to assess for any visual differences in the population starting weight, mean and range of fecal scores.

Individual piglet weight data collected at trial entry and completion was used to derive three outcome variables. The individual daily weight gain (iADG, g/ day) was calculated as overall weight gain/days in study. Then, a group-level outcome was calculated; the average daily weight gain (ADG) was calculated in gram per day (g/ day) as mean weight gain of each treatment group/ days in study. Duration variation was corrected for in statistical analyses.

To investigate whether there was a significant effect of treatment type on iADG and ADG, mixed effects linear regression models were fitted in Stata version 13.1 (Statacorp, TX). Treatment type was included as a fixed effect, and farm identity (1 to 5 ) as a random effect. The effect of gender (female or castrated male), pen identity and PDI were also examined as fixed effects in separate univariate models.
Mixed effects regression models were also used to examine the effect of treatment type (A to D) on fecal score, serum and tissue mineral levels in separate univariate models. Likelihood ratio tests were used to assess model significance. Model outcomes were described using coefficient $\beta$ (indicating the magnitude of the effect), the 95\% confidence interval $(\mathrm{CI})$ and Wald $p$-values [67]. To assess the effect of treatment type, the baseline $(\beta=0)$ for comparison of coefficient values was set as treatment $\mathrm{A}$ (peat containing $2819 \mathrm{mg} / \mathrm{L}$ uncoated $\mathrm{ZnO}$ ).

\section{Results}

\section{Peat preparation quality}

No pathogenic Mycobacteria avium were detected by applying IS901-IS902 specific primers on samples isolated from the peat preparation.

\section{Fecal scores}

Regression models found no effect of farm identity or pen identity or fecal score $(P>0.05)$. However, treatment type had a significant effect on fecal score $(P<0.05)$. Compared to pens of piglets receiving treatment $A(\beta=0)$, higher fecal scores, indicative of looser feces, were recorded in pens receiving lower levels of $\mathrm{Zn}$ inclusion - treatments $\mathrm{C}$ or $\mathrm{D}(P<0.05)$.

\section{Pen average daily weight gain (ADG) and individual daily} weight gain (iADG)

Outbreaks of PWD and ED on Farms 4 and 5 caused mortality rates of $2.9 \%$ and $6.2 \%$, respectively. Due to high mortality and reduced weight gain observed in affected piglets, data from Farms 4 and 5 were analyzed separately to look at the effects of different $\mathrm{ZnO}$-treatments on weight gain. A summary of weight gain results are listed in Table 4.

On farm 1, no significant effect of treatment was found for iADG. Gender did not have a significant effect on iADG.

Mixed-effects models identified significantly lower iADG $(P<0.05)$ in piglets receiving treatment $\mathrm{D}$, comparing with those receiving treatment $A$ at Farms 2 and 3 (Table 4). At Farm 2, iADG in treatment groups A, B, $\mathrm{C}$ and D were $410 \pm 90 \mathrm{~g} /$ day, $390 \pm 100 \mathrm{~g} /$ day, $340 \pm$ $150 \mathrm{~g} /$ day and $290 \pm 130 \mathrm{~g} /$ day.

At Farm 3, iADG in treatment groups A, B, C and D were $410 \pm 110 \mathrm{~g} /$ day, $370 \pm 100 \mathrm{~kg} /$ day, $270 \pm 80 \mathrm{~g} /$ day and $230 \pm 80 \mathrm{~g} /$ day.

\section{Effects on serum minerals and tissue $\mathrm{Zn}$ concentrations}

Data from Farms 2 and 3, indicated that serum Fe, P, $\mathrm{Cu}, \mathrm{Ca}$ and $\mathrm{Mg}$ levels were not influenced by treatment. Linear regression analysis suggested that treatment had an influence on serum $\mathrm{Zn}$ serum levels at Farm 2. Compared to treatments B-D, treatment A was associated 
with a significantly higher $\mathrm{Zn}$ concentration increase in serum after 14 days of treatment $(p<0.02)$. Mean serum $\mathrm{Zn}$ (SD) increase was $3.43(2.42) \mu \mathrm{mol} / \mathrm{L}$ and $1.71(2.25) \mu \mathrm{mol} / \mathrm{L}$ for treatments $\mathrm{A}$ and $\mathrm{B}$, respectively. Treatment $\mathrm{C}$ lead to an increase of 0.27 (2.32) $\mu \mathrm{mol}$ serum $\mathrm{Zn} / \mathrm{L}$ and treatment $\mathrm{D}$ lead to an increase of 1.03 (2.99) $\mu \mathrm{mol}$ serum Zn/ L. At Farm 3, no significant serum $\mathrm{Zn}$ increase was observed, when comparing initial and final $\mathrm{Zn}$ serum levels across all treatment groups.

Mean $\mathrm{Zn}$ concentrations ( $\mu \mathrm{g} / \mathrm{g}$ dry weight) in liver samples of piglets at Farm 2 receiving treatments A to D for 7 days were 31.9 (4.3), 25.5 (3.1), 20.9 (2.5) and 25.7 (1.8), respectively. Mean $\mathrm{Zn}$ concentrations ( $\mu \mathrm{g} / \mathrm{g}$ dry weight) in liver samples of piglets at Farm 2 receiving treatments A to D for 15 days were 57.8 (10.42), 51.37 (7.05), 29.30 (7.78) and 25.77 (3.98), respectively. Mean $\mathrm{Zn}$ concentrations $(\mu \mathrm{g} / \mathrm{g}$ dry weight) in kidneys of piglets at Farm 2 receiving treatments A to D for 7 days were 13.5 (0.9), 13.5 (0.8), $13.5(0.2)$ and $12.3(0.5)$, respectively. Mean Zn concentrations ( $\mu \mathrm{g} / \mathrm{g}$ dry weight) in kidneys of piglets at Farm 2 receiving treatments A to D for 15 days were 30.23 (6.91), 27.23 (9.42), 11.95 (4.03) and 11.06 (2.48), respectively.

\section{Clinical signs and bacteriology}

Bacteriological investigations of fecal material from piglets observed with clinical signs of diarrhea revealed that pathogenic E. coli strains were isolated from all five farms (Table 3). At Farm 1, ETEC and the two predominant virotypes STa:F5:F41 and LT:STb:F4 were isolated. Signs of diarrhea were evident across treatment groups at initiation of the trial. Only one pen in treatment group $\mathrm{C}$ showed

Table 3 Pathotyping and virotyping of E. coli strains isolated during trials at Farms 1 to 5

\begin{tabular}{llll}
\hline Farm & Pathotype & Virotype & Fimbriae and toxin prevalence (\%) \\
\hline 1 & ETEC & STa:F5:F41 & 50.0 \\
& & LT:STb & 12.5 \\
& & LT:STb:F4 & 37.5 \\
& ETEC & STa:STb & 13.3 \\
& & STa:STb:F4 & 13.3 \\
& & STxA & 13.3 \\
& & STb & 46.7 \\
& & STb:F18 & 6.7 \\
3 & LT:STb & 6.7 \\
4 & ETEC & F18 & 100.0 \\
5 & STEC & Stx2e:F18 & 100.0 \\
\hline
\end{tabular}

E. coli isolates from Farms 1 to 5. Pathotypes and virotypes are described. At Farms 1 to 4, the pathotype Enterotoxigenic E. coli (ETEC) was found. At Farm 5, Shiga-toxigenic E. coli (STEC) was present. At Farms 1 to 5, the predominant virotypes detected by multiplex PCR analysis were STa:F5:F41, STb, F18, LT:STb:F4 and Stx2e:F18, respectively signs of diarrhea until eight days into the trial. ETEC STb were the predominant pathotype and virotype at Farm 2 and clinical signs of diarrhea were seen at initiation of the trial in pens across treatment groups. The symptoms disappeared in all treatment groups except the group receiving no peat. At Farm 3, ETEC F18 ${ }^{+}$was found and clinical symptoms occurred seven days into the trial in pens where piglets received treatment $C$ and D. At Farm 4, ETEC LT:STb:F4 ${ }^{+}$was associated with an outbreak of sudden death affecting 16 piglets (2.9\% of the batch) within a one week period, starting 3 days prior to weaning. Postmortem examination revealed hemorrhagic enteritis in all examined piglets. At Farm 5, STEC Stx2e:F18 ${ }^{+}$caused sudden death of totally 24 piglets $(6.2 \%$ of the batch) within a two weeks period, the first cases occurred at weaning. Post-mortem examinations of several piglets revealed macroscopic pathological findings compatible with ED including subcutaneous edema, edema in the submucosa of the stomach and the mesocolon. One trial piglet in the control group (D) at Farm 3 died during the experimental period. Necropsy findings were consistent with a case of haemorrhagic enteritis caused by $E$. coli infection. Serotyping and multiplex PCR analysis revealed an E. coli $0138 \mathrm{~F}^{1} 8^{+}$strain.

\section{Discussion}

Therapeutic $\mathrm{ZnO}$ levels in diets for weaner pigs to prevent $E$. coli infections are widely used as an efficient and cost-effective preventive strategy for PWD or ED [68-70]. In Asia and the Americas, it has been standard procedure to apply up to $3000 \mathrm{ppm}$ of $\mathrm{ZnO}$ in weaners feed [71]. However, various studies have elucidated different challenges associated with this prophylactic approach including antimicrobial resistance and environmental pollution [25, 28, 29, 72-74]. This study aimed to identify whether peat supplemented with low-level uncoated or coated $\mathrm{ZnO}$ preparations could offer a feasible and effective alternative to conventional therapeutic $\mathrm{ZnO}$ levels for the reduction of $E$. coli associated diarrhea or ED. To the authors' knowledge, there are no previous reports on the effects of coated $\mathrm{ZnO}$ enriched peat on weaned piglets production parameters. Data from the present study supported our hypothesis that feeding $\mathrm{ZnO}$ enriched coated peat to weaned piglets for 14 days can achieve the combined beneficial effects of higher weight gain and reduced fecal scores. Additionally, the usage of coated $\mathrm{ZnO}$ to prevent enterotoxic colibacillosis can reduce $\mathrm{Zn}$ emmissions from swine producing units resulting in a substantially lower environmental impact.

An effect of treatment type on fecal consistency scores was found at Farms 1 to 3. Treatment $\mathrm{C}$ (commercial peat without $\mathrm{ZnO}$-additives) and treatment $\mathrm{D}$ (controls) resulted in significantly higher fecal scores than treatment A (2819 mg/L uncoated $\mathrm{ZnO})$ at Farms 1 to 3. 
These findings are consistent with a previously published study showing that 14 days of post weaning $\mathrm{ZnO}$ inclusion in feed affected fecal consistency, and that $3125 \mathrm{mg} / \mathrm{kg}$ of uncoated $\mathrm{ZnO}$ led to firmer fecal consistency than the inclusion of $139 \mathrm{mg} / \mathrm{kg}$ feed of a lipid encapsulated $\mathrm{ZnO}$ source called Shield $\mathrm{Zn}$ [75]. In the present study, basal diets at Farms 1-3 contained between $16 \%$ and $19.6 \%$ crude protein. Farms feeding diets containing crude protein levels below 19\% can be considered relatively low. Low-protein diets may have a diarrheareducing effect [76]. This, combined with a possibly suboptimal concentration of ZINCORET ${ }^{\mathrm{mm}}$ included in treatment B ( $321 \mathrm{mg} / \mathrm{L}$ coated $\mathrm{ZnO})$, may have concealed the presumptive effect on fecal consistency. Thus, any future studies including coated $\mathrm{ZnO}$ in peat may require concentrations above $321 \mathrm{mg} \mathrm{ZnO} / \mathrm{l}$ to promote significant effects on fecal consistency and growth rates. Other reports have described beneficial effects of coated $\mathrm{ZnO}$ on growth rates, intestinal morphology, digestive enzyme activity and colibacillosis at rates of 100 to $200 \mathrm{ppm}$ in basic feed to recently weaned piglets $[28,75,77]$.

$\mathrm{ZnO}$ treatment had no significant effect on ADG on Farms 1, 2 and 3. Large body weight variations within each group combined with a relatively low number of pens per treatment may have contributed to these results. No treatment effect on iADG was discovered at Farm 1. These piglets entered the study at three weeks of age. A possible explanation to the lack of statistical differences in weight gain across the groups at Farm 1, may be related to the fact that the farmer did not consent to include a control or untreated group (treatment D) due to concerns regarding $E$. coli associated diarrhea. At Farms 2 and 3, however, treatment D was included. Ear tagged piglets receiving treatments A showed higher iADG than piglets receiving treatment D. Individual animal identification through ear tagging and individual weight measurements of a larger number of piglets across the study farms could have provided stronger evidence to support the finding of growth promoting effects of $\mathrm{ZnO}$ enriched peat treatment identified on Farms 2 and 3.

Serum $\mathrm{Zn}$ serum levels at Farm 2 were influenced by the type of $\mathrm{Zn}$ treatment. Compared to treatment $\mathrm{A}$ (2819 $\mathrm{mg} / \mathrm{L}$ uncoated $\mathrm{ZnO})$, treatment B $(321 \mathrm{mg} / \mathrm{L}$ coated $\mathrm{ZnO}$ ), $\mathrm{C}$ (commercial peat without additives) and $\mathrm{D}$ (controls) were associated with significantly lower increases in serum $\mathrm{Zn}$ concentration after 14 days of treatment. Our results are consistent with previous studies, showing that inclusion of $\mathrm{ZnO}$ in the feed will increase the serum $\mathrm{Zn}$ concentrations [78-80].

Tissue samples from only three animals per treatment group were collected at days 7 and 15 of the first trial at Farm 2 due to limited financial resources. Although no statistically significant effects of treatment were seen on final $\mathrm{Zn}$ kidney and liver concentrations, the highest numerical increase of both liver and kidney $\mathrm{Zn}$ concentrations was observed in animals receiving treatment $\mathrm{A}$, followed by animals receiving treatments $\mathrm{B}, \mathrm{C}$ and $\mathrm{D}$, respectively.

These results are in line with previous findings, showing greater hepatic and circulating $\mathrm{Zn}$ concentrations in piglets receiving therapeutic concentrations of uncoated $\mathrm{ZnO}$ (between $2000 \mathrm{ppm}$ and $2500 \mathrm{ppm}$ ) than piglets fed 100 to $200 \mathrm{ppm}$ of coated $\mathrm{ZnO}[28,29,81]$. The mean $\mathrm{Zn}$ concentrations in liver samples from piglets receiving treatment A were $57.80(10.42) \mu \mathrm{g} / \mathrm{g}$ dry weight while $\mathrm{Zn}$ concentrations in liver samples from piglets receiving treatment $\mathrm{B}, \mathrm{C}$ and $\mathrm{D}$ were 51.37 (7.05) $\mu \mathrm{g} / \mathrm{g}$ dry weight, 29.30 (7.78) $\mu \mathrm{g} / \mathrm{g}$ dry weight and $25.77(3.98) \mu \mathrm{g} / \mathrm{g}$ dry weight, respectively.

Peat B contained $321 \mathrm{mg} / \mathrm{L}$ coated $\mathrm{ZnO}$ while Peat A contained $2819 \mathrm{mg} / \mathrm{L}$ uncoated $\mathrm{ZnO}$, equivalent with a ratio of 1:8.8. Despite the low coated versus high uncoated $\mathrm{ZnO}$ ratio in Peat $\mathrm{B}$ and Peat $\mathrm{A}$, comparable Zn-levels were detected in animals receiving Peat A or Peat B. These tissue $\mathrm{Zn}$ concentrations suggest that the bioavailability of coated $\mathrm{Zn}$ added to peat is higher than uncoated $\mathrm{Zn}$. Experimental studies on the pharmacological effects of $\mathrm{Zn}$ to reduce post-weaning scouring and improve body weight gain have shown that formulations of $\mathrm{Zn}$ in organic form or lipid-encapsulated $\mathrm{Zn}$ may be effective at relatively low concentrations, achieving comparable effect with far higher concentrations of inorganic $\mathrm{Zn}$. This indicates that the bioavailability and retention of organic form or lipid-encapsulated Zn may be increased [24]. A recent study demonstrates that nanosize $\mathrm{ZnO}$ can increase $\mathrm{Zn}$ digestibility, serum growth hormone levels and carbonic anhydrase activity and enhance the immune response of weanling piglets [82]. Uncoated $\mathrm{ZnO}$ tend to dissociate after uptake in the low $\mathrm{pH}$ environment of the anterior gastrointestinal tract, allowing interaction with other nutrient and ingredient potentially leading to impaired absorption, and thus decreased bioavailability [22].

The fecal Zn concentrations were not measured in this trial due to limited financial resources, but it seems likely that fecal $\mathrm{Zn}$ concentrations in feces from piglets receiving treatment $\mathrm{B}$ would be lower than $\mathrm{Zn}$ concentrations in feces from piglets receiving treatment $A$, as shown in previous studies [83-85].

Five farms with a history of $E$. coli associated enteric disease were specifically included in this study. Pathogenic $E$. coli strains were detected at all farms. During the course of the trial, clinical signs of disease were not evident on Farms 1 and 2. At Farm 3, one piglet died due to haemorrhagic enteritis associated with $E$. coli whilst Farms 4 and 5 experienced outbreaks of $E$. coli-associated peracute-toacute PWD and ED, respectively. The differences in clinical presentations may be explained by the fact that 
different pathotypes of $E$. coli were present at the different trial farms (Table 3). Possible coinfections with e.g. rotavirus [86], management, feeding and hygiene policies [87-89] may also have influenced the general enteric health and disease susceptibility among piglets at Farms 4 and 5. The detection of coinfection-causing agents was not included in this study. The passive protection of piglets against $E$. coli infections through vaccination of the dams decreases with ageing and lactogenic immunity suddenly stops at weaning [90]. It is likely that subclinical infections of the surviving weaned piglets at Farms 4 and 5 affected ADG. Reduced weight gain is indeed associated with subclinical infections in pigs [91-93]. Tables 4 shows that the ADG/ piglet in treatment groups A to $\mathrm{C}$ were low at Farms 4 and 5 where ETEC and STEC expressing the virulence factors LT:STb:F4 and Stx2e:F18 were found. Mortality rates of $2.9 \%$ at Farm 4 and $6.2 \%$ at Farm 5 during the first 2 weeks after weaning occurred in spite of prophylactic treatment with $\mathrm{ZnO}$ enriched peat. This may suggest that both uncoated or microencapsulated $\mathrm{ZnO}$ concentrations in peat require optimization to achieve broader preventive effects on piglets at farms with different infection pressure and $E$. coli variants.

The multiplex PCR results show that ETEC F4 ${ }^{+}$were found at both Farms 2 and 4 . There was a clear difference in strain virulence at these farms, which may be explained by differing management strategies. At Farm 2 a strict cleaning and disinfection regime between batches was maintained. This was not possible at Farm 4 due to poor growth rates and consequently a reduced duration of empty periods between batches. Additionally, a large amount of flies were present at Farm 4. Flies are known to transmit bacteria including E. coli $[94,95]$.

The actual daily consumption of peat per piglet was not feasible to measure in this study because piglets were kept in groups. Instead, an estimated daily piglet $\mathrm{Zn}$ consumption rate was calculated, by dividing the amount of daily added $\mathrm{Zn}$ in peat preparations by the number of piglets per pen $[96,97]$. This field trial demonstrated that significant growth promoting and diarrhea reducing effects were maintained by adding $2819 \mathrm{mg}$ uncoated $\mathrm{ZnO} / \mathrm{l}$ of peat (Treatment A). Pens of piglets receiving $2 \mathrm{~L}$ of peat per

Table 4 Average daily gain (ADG) results at Farms 1 to 5

\begin{tabular}{|c|c|c|c|c|c|c|c|c|}
\hline Farm & Treatment & Trial duration (days) & ADG (g/ day) & SEM & $\mathrm{n}=$ & iADG (g/ day) & SEM & $\mathrm{n}=$ \\
\hline \multirow[t]{3}{*}{$\overline{1}$} & $A$ & 21 & 270 & 12 & 6 & 270 & 12 & 57 \\
\hline & B & & 300 & 11 & 6 & 300 & 11 & 54 \\
\hline & C & & 280 & 12 & 6 & 280 & 12 & 57 \\
\hline \multirow[t]{4}{*}{2} & $A$ & $15 / 15$ & 400 & 12 & 9 & $410^{a}$ & 18 & 12 \\
\hline & $B$ & & 410 & 11 & 9 & 390 & 21 & 12 \\
\hline & C & & 340 & 10 & 9 & 340 & 31 & 12 \\
\hline & D & & 330 & 12 & 9 & $290^{b}$ & 27 & 12 \\
\hline \multirow[t]{4}{*}{3} & $A$ & $15 / 17$ & 400 & 5 & 6 & $410^{a}$ & 31 & 6 \\
\hline & B & & 370 & 10 & 6 & 370 & 29 & 6 \\
\hline & C & & 320 & 8 & 6 & 270 & 23 & 6 \\
\hline & D & & 370 & 8 & 6 & $230^{b}$ & 23 & 6 \\
\hline \multirow[t]{3}{*}{4} & A & 15 & 220 & 3 & 18 & \# & \# & $\#$ \\
\hline & B & & 210 & 2 & 18 & \# & \# & \# \\
\hline & C & & 190 & 4 & 17 & \# & \# & \# \\
\hline \multirow[t]{3}{*}{5} & A & $14 / 15$ & 230 & 8 & 12 & \# & \# & \# \\
\hline & B & & 240 & 8 & 12 & \# & \# & \# \\
\hline & C & & 210 & 7 & 12 & \# & \# & \# \\
\hline
\end{tabular}

The pen based and individual weight measurements are expressed as ADG/ piglet and iADG, respectively. Treatment A was peat containing $2819 \mathrm{mg} / \mathrm{L}$ uncoated $\mathrm{ZnO}$ (2255 mg Zn/L). Treatment B was peat containing 321 mg/L coated ZnO ( 257 mg Zn/L). Treatment C was commercial peat without ZnO-additives (36 mg Zn/L). Treatment $D$ implied no feeding of peat (control groups). Individual measurements of all piglets were included at Farm 1, both group and selected individual weight registrations were included at Farms 2 and 3. Group weight registrations only were included at Farms 4 and 5 . Significant differences $(P<0.05)$ between iADG at the Farms 2 and 3 are indicated by different superscripts (a or b). At Farm 3, two trials with differing duration were conducted without affecting the weight gain of piglets significantly (data not shown). Variation in trial durations were based on the need for farmers compliance to participate in the trials and the practicality at each farm. Duration variation was corrected for in statistical analyses

\#Not included in the trial 
day, received $5638 \mathrm{mg} \mathrm{ZnO}$ per day, which equals to $4510 \mathrm{mg} \mathrm{Zn}$. Each piglet (10 to 12/ pen) should theoretically consume approximately between $451 \mathrm{mg} \mathrm{Zn}$ and $376 \mathrm{mg} \mathrm{Zn}$ per day. Treatments B equated to an approximate daily $\mathrm{Zn}$ uptake per piglet between $51 \mathrm{mg} \mathrm{Zn}$ per day and $43 \mathrm{mg} Z \mathrm{Zn}$ per day. Treatment $\mathrm{C}$ equated to an approximate daily $\mathrm{Zn}$ uptake per piglet between $7 \mathrm{mg} \mathrm{Zn}$ per day and $6 \mathrm{mg} \mathrm{Zn}$ per day. These levels of $\mathrm{Zn}$ uptake per piglet per day are much lower than the uptake levels when applying conventional pharmacological concentrations of $\mathrm{ZnO}$ in pelleted feed to piglets. If assuming a mean daily feed consumption of $450 \mathrm{~g} /$ day during the first 14 days after weaning (32 days old piglets) [98, 99], piglets receiving conventional pharmacological levels of uncoated $\mathrm{ZnO}$ between 2000 and 3500 ppm (1600 and $2800 \mathrm{ppm} \mathrm{Zn}$, respectively) added to their basal diet will consume between 720 and $1260 \mathrm{mg} \mathrm{Zn}$ per day, respectively. A comparison of feeding Peat A or Peat B with a diet added $2000 \mathrm{ppm}$ uncoated $\mathrm{ZnO}$ (or $1600 \mathrm{ppm}$ $\mathrm{Zn}$ ) implicates a reduction of dietary $\mathrm{Zn}$ by $72.0 \%$ (Peat A) or even $96.8 \%$ (Peat B).

\section{Conclusions}

To the author's knowledge, this is the first field study undertaken to identify effects of supplementation with both uncoated and coated $\mathrm{ZnO}$-enriched peat on fecal consistency and weight gain. This study has practical relevance for the control of enteric diseases in weaned piglets managed under European pig production systems. Since higher iADG was observed in a relatively small sample size of piglets receiving treatment A, our findings support the need for further research, conducted on a larger number of farms and under varying management conditions. The determination of optimal $\mathrm{ZnO}$ concentrations in peat preparations for growthenhancing as well as PWD and ED preventive effects needs further investigation. Additionally, our promising findings support further investigation on coated $\mathrm{ZnO}$ in a larger randomized clinical trial, either added to peat or concentrates. Coated $\mathrm{ZnO}$ represents an alternative to reduce the negative impact on the environment and a way of counteracting potential co-selection for antibiotic resistance in bacteria.

In light of the current discussion regarding a possible ban on the use of $\mathrm{ZnO}$ in animal feed, it is important to emphasize that the usage of orally administered veterinary medicinal products containing $\mathrm{ZnO}$ should be reduced. Simultaneously, optimization of management strategies at pig producing units should always be strived for prior to applying $\mathrm{ZnO}$ as a preventive measure to avoid PWD or ED.

\section{Abbreviations}

ADG: Average daily weight gain; AR: Antibiotic resistance; Ca: Calcium; Cl: Confidence interval; Cp: Ceruloplasmin; Cu: Copper; E. coll: Escherichia coli;
ED: Edema disease; ETEC: Enterotoxigenic E. coli; Fe: Iron; g: Gram; HH: Hampshire/Hampshire; iADG: Individual weight gain; L: Liter; LD: Landrace/ Duroc; LL: Landrace x Landrace; LT: Heat-labile enterotoxin; LY: Landrace $x$ Yorkshire; Mg: Magnesium; P: Inorganic phosphate; PCR: Polymerase chain reaction; PWD: Post-weaning diarrhea; Stb: Heat-stable enterotoxin B; STEC: Shiga-toxigenic E. coli; Zn: Zinc

\section{Acknowledgements}

The Authors wish to acknowledge the contributions of Fossli AS and the farmers involved in this study.

\section{Funding}

This study was financed by SINTEF, Norway.

\section{Availability of data and materials}

The datasets generated during the current study are kept and stored by the corresponding author. The datasets used and/or analysed during the current study are available from the corresponding author on reasonable request.

\section{Authors' contributions}

AKF and HS analyzed the bacteria isolates. MOM, CAG and TF conducted the field trials while $C P$ analyzed the data statistically. MOM, CAG, CP, HS and TF were major contributors in writing the manuscript. All authors read and approved the final manuscript.

\section{Competing interests}

The authors declare that they have no competing interests.

\section{Consent for publication}

Not applicable.

\section{Ethics approval and consent to participate}

All farmers included in this study gave their consent to participate, based on the fact that the experiments described in this article were conducted in accordance with the laws and regulations controlling experiments in live animals in Norway, including the Animal Welfare Act of November 17th 1998, chapter I and the Regulation of Animal Experimentation 15th January 1996.

\section{Publisher's Note}

Springer Nature remains neutral with regard to jurisdictional claims in published maps and institutional affiliations.

\section{Author details \\ ${ }^{1}$ Department of Production Animal Clinical Sciences, Norwegian University of Life Sciences (NMBU) Faculty of Veterinary Medicine, Campus Sandnes, Sandnes, Norway. ${ }^{2}$ Norwegian Veterinary Institute, Oslo, Norway. ${ }^{3}$ Faculty of Veterinary Medicine, Department of Food Safety and Infection Biology, Norwegian University of Life Sciences, Oslo, Norway. ${ }^{4}$ Department of Production Animal Clinical Sciences, Norwegian University of Life Sciences (NMBU) Faculty of Veterinary Medicine, Campus Adamstuen, Adamstuen, Norway.}

Received: 13 January 2017 Accepted: 16 May 2017

Published online: 28 June 2017

\section{References}

1. Nguyen UV, Melkebeek V, Devriendt B, Goetstouwers T, Van Poucke M, Peelman $L$, et al. Maternal immunity enhances systemic recall immune responses upon oral immunization of piglets with F4 fimbriae. Vet Res. 2015;46:72. doi:10.1186/s13567-015-0210-3.

2. Sieverding E. Handbuch Gesunde Schweine. Germany: Kamlage Verlag; 2000.

3. Bailey M, Clarke CJ, Wilson AD, Williams NA, Stokes CR. Depressed potential for interleukin-2 production following early weaning of piglets. Vet Immunol Immunopathol. 1992;34:197-207.

4. Hessing MJC, Coenen GJ, Vaiman M, Renard C. Individual differences in cellmediated and humoral immunity in pigs. Vet Immunol Immunopathol. 1995:45:97-113. doi:10.1016/0165-2427(94)05338-S.

5. Wattrang $E$, Wallgren $P$, Lindberg A, Fossum C. Signs of infections and reduced immune functions at weaning of conventionally reared and specific pathogen free pigs. Zentralbl Veterinärmed B. 1998:45:7-17. 
6. Melin L, Wallgren P. Aspects on Feed Related Prophylactic Measures Aiming to Prevent Post Weaning Diarrhoea in Pigs. Acta Vet Scand. 2002:43:231. doi:10.1186/1751-0147-43-231.

7. Quiñonero J, Ramis G, Lopes E, María-Dolores E, Armero E. Effect of mixing piglets affected by Escherichia coli diarrhea on growth and welfare responses. J Swine Health Prod. 2012;20:216-22.

8. Svensmark B, Jorsal SE, Nielsen K, Willeberg P. Epidemiological studies of piglet diarrhoea in intensively managed Danish sow herds. I. Pre-weaning diarrhoea. Acta Vet Scand. 1989;30:43-53.

9. Svensmark B, Nielsen K, Willeberg P, Jorsal SE. Epidemiological studies of piglet diarrhoea in intensively managed Danish sow herds. II. Post-weaning diarrhoea. Acta Vet Scand. 1989;30:55-62.

10. Broes A, Fairbrother JM, Jacques M, Larivière S. Requirement for capsular antigen KX105 and fimbrial antigen CS1541 in the pathogenicity of porcine enterotoxigenic Escherichia coli O8:KX105 strains. Can J Vet Res. 1989;53:43-7.

11. Helgerson AF, Sharma V, Dow AM, Schroeder R, Post K, Cornick NA. Edema Disease Caused by a Clone of Escherichia coli O147. J Clin Microbiol. 2006; 44:3074-7. doi:10.1128/JCM.00617-06.

12. Nagy B, Fekete PZ. Enterotoxigenic Escherichia coli (ETEC) in farm animals. Vet Res. 1999;30:259-84.

13. Bertschinger HU, Gyles CL. Escherichia coli in domestic animals and humans; Oedema disease of pigs. In: Oedema Dis. Pigs. Wallingford: CAB International; 1994. p. 193-219.

14. European Commission. Ban on antibiotics as growth promoters in animal feed enters into effect. 2005. http://europa.eu/rapid/press-release_IP-051687_en.htm. Accessed 19 Oct 2016.

15. Food and Agriculture Organization of the United Nations (FAO). Antibiotics in Farm Animal Production Public health and animal welfare. 2011. http:// www.fao.org/fileadmin/user_upload/animalwelfare/antibiotics_in_animal_ farming.pdf. Accessed 15 Feb 2017.

16. Li X, Yin J, Li D, Chen X, Zang J, Zhou X. Dietary supplementation with zinc oxide increases Igf-I and Igf-I receptor gene expression in the small intestine of weanling piglets. J Nutr. 2006;136:1786-91.

17. Carlson MS, Hill GM, Link JE. Early- and traditionally weaned nursery pigs benefit from phase-feeding pharmacological concentrations of zinc oxide: effect on metallothionein and mineral concentrations. J Anim Sci. 1999:77:1199-207.

18. Zhang B, Guo Y. Supplemental zinc reduced intestinal permeability by enhancing occludin and zonula occludens protein-1 (ZO-1) expression in weaning piglets. Br J Nutr. 2009;102:687-93. doi:10.1017/S0007114509289033.

19. Jensen-Waern $M$, Melin $L$, Lindberg $R$, Johannisson $A$, Petersson $L$, Wallgren $P$. Dietary zinc oxide in weaned pigs - effects on performance, tissue concentrations, morphology, neutrophil functions and faecal microflora. Res Vet Sci. 1998;64:225-31. doi:10.1016/S0034-5288(98)90130-8.

20. Højberg O, Canibe N, Poulsen HD, Hedemann MS, Jensen BB. Influence of dietary zinc oxide and copper sulfate on the gastrointestinal ecosystem in newly weaned piglets. Appl Environ Microbiol. 2005;71:2267-77. doi:10. 1128/AEM.71.5.2267-2277.2005

21. Katouli M, Melin L, Jensen-Waern M, Wallgren $P$, Möllby $R$. The effect of zinc oxide supplementation on the stability of the intestinal flora with specia reference to composition of coliforms in weaned pigs. J Appl Microbiol. 1999;87:564-73.

22. Suttle NF. Mineral Nutrition of Livestock. 4th ed. Oxfordshire: CAB International: 2010

23. Åhman M. Zinc flow to the soil in Swedish piglet production. 2013. http:// stud.epsilon.slu.se/5322/. Accessed 16 Feb 2017.

24. Norwegian Scientific Committee for Food Safety. Zinc and copper in pig and poultry production - fate and effects in the food chain and the environment. 2014. http://www.english.vkm.no/dav/3b1b6769dd.pdf. Accessed 22 Feb 2017

25. Dourmad J-Y, Jondreville C. Impact of nutrition on nitrogen, phosphorus, $\mathrm{Cu}$ and $\mathrm{Zn}$ in pig manure, and on emissions of ammonia and odours. Livest Sci. 2007:112:192-8. doi:10.1016/j.livsci.2007.09.002.

26. European Union. Commision Regulation No 1334/2003 amending the conditions for authorisation of a number of additives in feedingstuffs belonging to the group of trace elements. 2003. http://eur-lex.europa.eu/ legal-content/EN/TXT/?uri=CELEX\%3A32003R1334. Accessed 22 Feb 2017

27. Baker-Austin C, Wright MS, Stepanauskas R, McArthur JV. Co-selection of antibiotic and metal resistance. Trends Microbiol. 2006;14:176-82. doi:10. 1016/j.tim.2006.02.006.

28. Bednorz C, Oelgeschläger K, Kinnemann B, Hartmann S, Neumann K, Pieper R, et al. The broader context of antibiotic resistance: zinc feed supplementation of piglets increases the proportion of multi-resistant Escherichia coli in vivo. Int J Med Microbiol. 2013;303:396-403. doi:10.1016/j.jimm.2013.06.004.

29. Cavaco LM, Hasman H, Aarestrup FM. Zinc resistance of Staphylococcus aureus of animal origin is strongly associated with methicillin resistance. Vet Microbiol. 2011;150:344-8. doi:10.1016/j.vetmic.2011.02.014.

30. Hölzel CS, Müller C, Harms KS, Mikolajewski S, Schäfer S, Schwaiger K, et al. Heavy metals in liquid pig manure in light of bacterial antimicrobial resistance. Environ Res. 2012;113:21-7. doi:10.1016/j.envres.2012.01.002.

31. Seiler C, Berendonk TU. Heavy metal driven co-selection of antibiotic resistance in soil and water bodies impacted by agriculture and aquaculture. Front Microbiol. 2012;3:399. doi:10.3389/fmicb.2012.00399.

32. Vahjen W, Pietruszyńska D, Starke IC, Zentek J. High dietary zinc supplementation increases the occurrence of tetracycline and sulfonamide resistance genes in the intestine of weaned pigs. Gut Pathog. 2015;7. doi:10.1186/s13099-015-0071-3.

33. Kwon C-H, Lee CY, Han S-J, Kim S-J, Park B-C, Jang I, et al. Effects of dietary supplementation of lipid-encapsulated zinc oxide on colibacillosis, growth and intestinal morphology in weaned piglets challenged with enterotoxigenic Escherichia coli. Anim Sci J Nihon Chikusan Gakkaihō. 2014; 85:805-13. doi:10.1111/asj.12215.

34. Kim SJ, Kwon CH, Park BC, Lee CY, Han JH. Effects of a lipidencapsulated zinc oxide dietary supplement, on growth parameters and intestinal morphology in weanling pigs artificially infected with enterotoxigenic Escherichia coli. J Anim Sci Technol. 2015:57. doi:10.1186/s40781-014-0038-9.

35. Shen J, Chen Y, Wang Z, Zhou A, He M, Mao L, et al. Coated zinc oxide improves intestinal immunity function and regulates microbiota composition in weaned piglets. Br J Nutr. 2014;111:2123-34. doi:10.1017/ S0007114514000300

36. Jang I, Kwon CH, Ha DM, Jung DY, Kang SY, Park MJ, et al. Effects of a lipidencapsulated zinc oxide supplement on growth performance and intestinal morphology and digestive enzyme activities in weanling pigs. J Anim Sci Technol. 2014;56 doi:10.1186/2055-0391-56-29.

37. Roost H, Dobberstein I, Kuntsch G, Berber H, Tardel H, Benda A, et al. Results and experience obtained from use of peat paste in industrialized piglet raising (in German). Monatsh Veterinärmed. 1990;45:239-43.

38. Trckova M, Matlova L, Hudcova H, Faldyna M, Zraly Z, Dvorska L, et al. Peat as a feed supplement for animals: a review. Vet Med. 2005:50:361-77.

39. Fuchs B, Orda J, Preś J, Muchowicz M. The effect of feeding piglets up to the 100th day of their life with peat preparation on their growth and physiological and biochemical indices. Arch Vet Pol Pol Acad Sci Comm Vet Sci. 1995;35:97-107.

40. Stackhouse RA, Benson WH. Interaction of humic acid with selected trace metals: Influence on bioaccumulation in daphnids. Environ Toxicol Chem. 1989:8:639-44. doi:10.1002/etc.5620080711.

41. Stackhouse RA, Benson WH. The effect of humic acid on the toxicity and bioavailability of trivalent chromium. Ecotoxicol Environ Saf. 1989:17:105-11.

42. Beer AM, Sagorchev P, Lukanov J. Isolation of biologically active fractions from the water soluble components of fulvic and ulmic acids from peat Phytomed Int J Phytother Phytopharm. 2002;9:659-66. doi:10.1078/ 094471102321616490

43. Kuhnert M, Fuchs V, Golbs S. Chemical characterization and pharmacologico-toxicological peculiarities of humic acid (in German). Arch Für Exp Veterinärmed. 1982;36:169-77.

44. Kuhnert M, Bartels KP, Kroll S, Lange N. Veterinary pharmaceuticals containing humic acid for therapy and prophylaxis for gastrointestinal diseases of dog and cat (in German). Monatsh Veterinärmed. 1991;46:4-8.

45. Fuchs $\mathrm{V}$, Kuhnert M, Golbs S, Dedek W. The enteral absorption of iron (II) from humic acid-iron complexes in suckling piglets using radiolabeled iron (59Fe) (in German). Dtsch Tierärztl Wochenschr. 1990:97:208-9.

46. Ji F, McGlone JJ, Kim SW. Effects of dietary humic substances on pig growth performance, carcass characteristics, and ammonia emission. J Anim Sci. 2006:84:2482-90. doi:10.2527/jas.2005-206.

47. Johansen TB, Agdestein A, Lium B, Jørgensen A, Djønne B, et al. Mycobacterium avium subsp. hominissuis Infection in Swine Associated with Peat Used for Bedding, Mycobacterium avium subsp. hominissuis Infection in Swine Associated with Peat Used for Bedding. Biomed Res Int. 2014:2014:e189649. doi:10.1155/2014/189649.

48. Matlova L, Kaevska M, Moravkova M, Beran V, Shitaye VE, Pavlik I. Mycobacteria in peat used as a supplement for pigs: failure of different decontamination methods to eliminate the risk. Vet Med (Praha). 2012;57:212-7. 
49. European Union. Commission Regulation (EC) No 152/2009 laying down the methods of sampling and analysis for the official control of feed. http://eurlex.europa.eu/legal-content/EN/ALL/?uri=CELEX\%3A32009R0152. 2009. Accessed 22 Feb 2017.

50. International Organization for Standardization. ISO 6869:2000 - Animal feeding stuffs - Determination of the contents of calcium, copper, iron, magnesium, manganese, potassium, sodium and zinc. Method using atomic absorption spectrometry. 2000. http://www.iso.org/iso/catalogue_detail. htm?csnumber=33707. Accessed 30 Dec 2016.

51. NordVal International. Mould and yeasts. Determination in foods and feed. 2005. http://www.nmkl.org/index.php/nb/webshop/item/nmkl-98. Accessed 30 Dec 2016.

52. NordVal International. 3MTM PetrifilmTM E.coli/ Coliform Count Plate NordVal International Certificate. 2003. http://www.nmkl.org/dokumenter/ nytt/90-no.pdf. Accessed 16 Feb 2017.

53. 3M Microbiology. 3MTM TecraTM Salmonella Visual Immunoassay (VIA). 2008. http://www.mdairysolutions.com/Brochures/other_food/3M salmonella.pdf. Accessed 14 Feb 2017.

54. Standard Norge. Water quality - Determination of pH (ISO 10523:2008). 2008. https://www.standard.no/no/Nettbutikk/produktkatalogen/ Produktpresentasjon/?Product|D=681000. Accessed 17 Feb 2017.

55. Poulsen HD. Zinc oxide for weanling piglets. Acta Agric Scand Sect A Anim Sci. 1995:45:159-67.

56. Agdestein A, Johansen TB, Polaček V, Lium B, Holstad G, Vidanović D, et al. Investigation of an outbreak of mycobacteriosis in pigs. BMC Vet Res. 2011; 7:63. doi:10.1186/1746-6148-7-63.

57. Ahrens P, Giese SB, Klausen J, Inglis NF. Two markers, IS901-IS902 and p40, identified by PCR and by using monoclonal antibodies in Mycobacterium avium strains. J Clin Microbiol. 1995;33:1049-53.

58. Lee CH, Moseley SL, Moon HW, Whipp SC, Gyles CL, So M. Characterization of the gene encoding heat-stable toxin II and preliminary molecular epidemiological studies of enterotoxigenic Escherichia coli heat-stable toxin II producers. Infect Immun. 1983;42:264-8.

59. So M, McCarthy BJ. Nucleotide sequence of the bacterial transposon Tn1618 encoding a heat-stable (ST) toxin and its identification in enterotoxigenic $E$. coli strains. Proc Natl Acad Sci. 1980:77:4011-2015.

60. Dallas WS, Falkow S. Amino acid sequence homology between cholera toxin and Escherichia coli heat-labile toxin. Nature. 1980;288:499-501.

61. Weinstein DL, Jackson MP, Samuel JE, Holmes RK, O'Brien AD. Cloning and sequencing of a Shiga-like toxin type II variant from Escherichia coli strain responsible for edema disease of swine. J Bacteriol. 1988;170: 4223-30.

62. Josephsen J, Hansen F, de Graaf FK, Gaastra W. The nucleotide sequence of the protein subunit of the K88ac fimbriae of porcine enterotoxigenic Escherichia coli. FEMS Microbiol Lett. 1984:25:301-6.

63. Roosendaal $E$, Jacobs AA, Rathman $P$, Sondermeyer $C$, Stegehuis $F$, Oudega B, et al. Primary structure and subcellular localization of two fimbrial subunit-like proteins involved in the biosynthesis of K99 fibrillae. Mol Microbiol. 1987:1:211-7.

64. de Graaf FK, Klaasen P. Nucleotide sequence of the gene encoding the 987P fimbrial subunit of Escherichia coli. FEMS Microbiol Lett. 1987;42:253-8. doi:10.1111/j.1574-6968.1987.tb02082.x.

65. Imberechts H, De Greve H, Schlicker C, Bouchet H, Pohl P, Charlier G, et al. Characterization of F107 fimbriae of Escherichia coli 107/86, which causes edema disease in pigs, and nucleotide sequence of the F107 major fimbrial subunit gene, fedA. Infect Immun. 1992;60:1963-71.

66. Anderson DG, Moseley SL. Escherichia coli F41 adhesin: genetic organization, nucleotide sequence, and homology with the K88 determinant. J Bacteriol. 1988;170:4890-6.

67. Long JS, Freese J. Regression Models for Categorical Dependent Variables using Stata. 2nd edn. College Station: StataCorp LP; 2006.

68. Poulsen HD, Carlson D. Zinc and copper for piglets- how do high dietary levels of these minerals function, Trace Elem Anim Prod Syst. Wageningen Wageningen Academic Publishers; 2008. p. 151-60.

69. Pettigrew JE. Reduced Use of Antibiotic Growth Promoters in Diets Fed to Weanling Pigs: Dietary Tools, Part 1. Anim Biotechnol. 2006;17:207-15. doi: 10.1080/10495390600956946.

70. Hollis GR, Carter SD, Cline TR, Crenshaw TD, Cromwell GL, Hill GM, et al. Effects of replacing pharmacological levels of dietary zinc oxide with lower dietary levels of various organic zinc sources for weanling pigs. J Anim Sci. 2005;83:2123-9.
71. Starke IC, Pieper R, Neumann K, Zentek J, Vahjen W. The impact of high dietary zinc oxide on the development of the intestinal microbiota in weaned piglets. FEMS Microbiol Ecol. 2014;87:416-27. doi:10.1111/1574-6941.12233.

72. Poulsen HD, Larsen T. Zinc excretion and retention in growing pigs fed increasing levels of zinc oxide. Livest Prod Sci. 1995:43:235-42.

73. Jondreville C, Revy PS, Dourmad JY. Dietary means to better control the environmental impact of copper and zinc by pigs from weaning to slaughter. Livest Prod Sci. 2003;84:147-56. doi:10.1016/j.livprodsci.2003.09.011.

74. Yazdankhah S, Rudi K, Bernhoft A. Zinc and copper in animal feed development of resistance and co-resistance to antimicrobial agents in bacteria of animal origin. Microb Ecol Health Dis. 2014;25 doi:10.3402/ mehd.v25.25862.

75. Park BC, Jung DY, Kang SY, Ko YH, Ha DM, Kwon CH, et al. Effects of dietary supplementation of a zinc oxide product encapsulated with lipid on growth performance, intestinal morphology, and digestive enzyme activities in weanling pigs. Anim Feed Sci Technol. 2015;200:112-7. doi:10.1016/j. anifeedsci.2014.11.016.

76. Heo JM, Kim JC, Hansen CF, Mullan BP, Hampson DJ, Pluske JR. Feeding a diet with decreased protein content reduces indices of protein fermentation and the incidence of postweaning diarrhea in weaned pigs challenged with an enterotoxigenic strain of Escherichia coli. J Anim Sci. 2009;87:2833-43. doi:10.2527/jas.2008-1274.

77. Kim JC, Hansen CF, Pluske JF, Mullan BP. Evaluating the replacement of zinc oxide with an encapsulated zinc oxide product as a means of controlling post-weaning diarrhoea in piglet. 2010. https://apri.com.au/2C-114_Final_ report.pdf. Accessed 22 Feb 2017.

78. Walk CL, Srinongkote $\mathrm{S}$, Wilcock $\mathrm{P}$. Influence of a microbial phytase and zinc oxide on young pig growth performance and serum minerals. J Anim Sci. 2013:91:286-91. doi:10.2527/jas.2012-5430.

79. Walk CL, Wilcock P, Magowan E. Evaluation of the effects of pharmacological zinc oxide and phosphorus source on weaned piglet growth performance, plasma minerals and mineral digestibility. Anim Int J Anim Biosci. 2015:9:1145-52. doi:10.1017/S175173111500035X

80. Schell TC, Kornegay ET. Zinc concentration in tissues and performance of weanling pigs fed pharmacological levels of zinc from $\mathrm{ZnO}, \mathrm{Zn}$-methionine, Zn-lysine, or ZnSO4. J Anim Sci. 1996;74:1584-93.

81. Jensen-Waern M, Melin L, Lindberg R, Johannisson A, Petersson L, Wallgren $P$. Dietary zinc oxide in weaned pigs-effects on performance, tissue concentrations, morphology, neutrophil functions and faecal microflora. Res Vet Sci. 1998;64:225-31.

82. Li M-Z, Huang J-T, Tsai Y-H, Mao S-Y, Fu C-M, Lien T-F. Nanosize of zinc oxide and the effects on zinc digestibility, growth performances, immune response and serum parameters of weanling piglets. Anim Sci J. 2016;87: 1379-85. doi:10.1111/asj.12579.

83. Carlson MS, Boren CA, Wu C, Huntington CE, Bollinger DW, Veum TL. Evaluation of various inclusion rates of organic zinc either as polysaccharide or proteinate complex on the growth performance, plasma, and excretion of nursery pigs. J Anim Sci. 2004;82:1359-66.

84. Buff CE, Bollinger DW, Ellersieck MR, Brommelsiek WA, Veum TL. Comparison of growth performance and zinc absorption, retention, and excretion in weanling pigs fed diets supplemented with zinc-polysaccharide or zinc oxide. J Anim Sci. 2005:83:2380-6.

85. Wang C, Xie P, Liu LL, Lu JJ, Zou XT. Effects of Dietary Capsulated Zinc Oxide on Growth Performance, Blood Metabolism and Mineral Concentrations in Weaning Piglets. Asian J Anim Vet Adv. 2013;8:502-10.

86. Dewey C, Carman S, Pasma T, Josephson G, McEwen B. Relationship between group A porcine rotavirus and management practices in swine herds in Ontario. Can Vet J. 2003; 44:649-653.

87. Frydendahl K. Prevalence of serogroups and virulence genes in Escherichia coli associated with postweaning diarrhoea and edema disease in pigs and a comparison of diagnostic approaches. Vet Microbiol. 2002;85:169-82.

88. van Beers-Schreurs HM, Vellenga L, Wensing T, Breukink HJ. The pathogenesis of the post-weaning syndrome in weaned piglets: a review. Vet Q. 1992;14:29-34. doi:10.1080/01652176.1992.9694322.

89. Bosworth BT, Samuel JE, Moon HW, O'Brien AD, Gordon VM, Whipp SC. Vaccination with genetically modified Shiga-like toxin lle prevents edema disease in swine. Infect Immun. 1996;64:55-60.

90. Cox E, Melkebeek V, Devriendt B, Goddeeris B, Vanrompay D. Vaccines against enteric E.coli infections in animals, Pathog Escherichia coli Mol Cell Microbiol. Caister: Academic Press; 2014. p. 255-70. 
91. Rohrbach BW, Hall RF, Hitchcock JP. Effect of subclinical infection with Actinobacillus pleuropneumoniae in commingled feeder swine. J Am Vet Med Assoc. 1993;202:1095-8.

92. Kurmann, J. Subclinical porcine circovirus infection significantly decreases growth parameters of fatteningpigs. 2011. University of Zurich. http://www. zora.uzh.ch/59592/2/Diss Kurmann_J Titel.pdf. Accessed 18 Feb 2017.

93. Jacobs AAC. A vaccine for use against subclinical lawsonia infection in a pig. 2016. https://www.google.com/patents/WO2016124623A1?cl=en. Accessed 20 Feb 2017.

94. Usui M, Shirakawa T, Fukuda A, Tamura Y. The Role of Flies in Disseminating Plasmids with Antimicrobial-Resistance Genes Between Farms. Microb Drug Resist. 2015;21:562-9. doi:10.1089/mdr.2015.0033.

95. Literak I, Dolejska M, Rybarikova J, Cizek A, Strejckova P, Vyskocilova M, et al. Highly variable patterns of antimicrobial resistance in commensal Escherichia coli isolates from pigs, sympatric rodents, and flies. Microb Drug Resist. 2009;15:229-37. doi:10.1089/mdr.2009.0913.

96. Spreeuwenberg MA, Verdonk JM, Gaskins HR, Verstegen MW. Small intestine epithelial barrier function is compromised in pigs with low feed intake at weaning. J Nutr. 2001;131:1520-7.

97. Campbell JM, Crenshaw JD, Polo J. The biological stress of early weaned piglets. J Anim Sci Biotechnol. 2013;4:19. doi:10.1186/2049-1891-4-19.

98. Carr J. Garth Pig Stockmanship Standards. Sheffield: 5m Publishing; 1998.

99. Kjelvik O, Bøe KE. Vanntildeling til avvent smågris. 2013. http://www.umb. no/statisk/husdyrforsoksmoter/2009/13.pdf. Accessed 19 Feb 2017.

\section{Submit your next manuscript to BioMed Central} and we will help you at every step:

- We accept pre-submission inquiries

- Our selector tool helps you to find the most relevant journal

- We provide round the clock customer support

- Convenient online submission

- Thorough peer review

- Inclusion in PubMed and all major indexing services

- Maximum visibility for your research

Submit your manuscript at www.biomedcentral.com/submit 